\title{
A INSERÇÃO DOS ESTUDOS DE GÊNERO NAS CIÊNCIAS DAS RELIGIÕES NO BRASIL: UM OLHAR A PARTIR DAS CIÊNCIAS SOCIAIS
}

\author{
THE INSERTION OF GENDER STUDIES IN THE SCIENCES OF RELIGIONS IN \\ BRAZIL: A VIEWPOINT FROM THE SOCIAL SCIENCES
}

Antonio Leonardo Figueiredo Calou ${ }^{1}$

\begin{abstract}
Resumo: Historicamente, o entrecruzamento dos estudos de gênero e religião consiste de uma problemática pouco discutida. Durante décadas de pesquisa em religião, as ciências sociais da religião deslegitimaram o discurso das mulheres acadêmicas, pensando e ressaltando sobre elas os mesmos discursos de constituições teóricas e metodológicas tradicionais, em sua maioria de base positivista. Com o advento da revolução feminista, surgem várias pesquisadoras dispostas a desmistificar essas constituições, mostrando a incapacidade de tais concepções e enfatizando, por vezes, a confessionalidade delas para com instituições religiosas. Como constituinte do rol de ciências que compõe o universo das Ciências das Religiões, estes escritos constituem uma tentativa de questionar como se apresentou, no curso da história, a inserção dos estudos de gênero no jovem campo das Ciências das Religiões no Brasil. Nessa perspectiva, pretende-se, também, apresentar uma visão socioantropológica da discussão acerca da equação gênero e religião para as Ciências Sociais e as Ciências das Religiões, sobre a apresentação de personagens e instituições importantes para a formação da discussão no país.
\end{abstract}

Palavras-Chave: Ciências Sociais; Ciências das Religiões; Gênero e Religião.

\begin{abstract}
Historically the intertwining of studies the gender and religion is a problematic little discussed. Throughout decades of research in religion, thesocial sciences of religion wasn't legitimized the discourse of academic women, thinking and emphasizing about them as the same discourses of traditional theoretical and methodological constitutions, in affinity and majority of positivist bases. With the arising of the feminist revolution, several researchers are ready to demystify these constitutions, showing the incapacity of such conceptions and oftentimes emphasizing their confessionality towards religious institutions. As a constituent of the role of sciences that compose the universe of the Sciences of Religions, these writings, in a certain attempt, to question how the insertion of gender studies in the newarea of the Sciences of Religions in Brazil was presented in the course of history. It will be sought to present a socio-anthropological vision of the discussion about the gender and religion equation for the Social Sciences and the Sciences of Religions, on the presentation of important characters and institutions for the formation of the discussion in the country.
\end{abstract}

Keywords: Social Sciences; Sciences of Religions; Genre and Religion.

\footnotetext{
1 Mestrando em Ciências das Religiões pela Universidade Federal da Paraíba (UFPB), sob a área de concentração em Ciências Sociais das Religiões, Educação e Saúde. leo.calou@hotmail.com
} 


\section{Introdução}

No presente artigo, trago uma produção interpretativa acerca da inserção dos estudos de gênero no âmbito da formação dos programas de pós-graduação da jovem Ciência das Religiões, enfatizando o contexto brasileiro. Tal interpretação segue os caminhos percorridos pelas Ciências Sociais da Religião e os diálogos, críticas e embates com os estudos de gênero. Busco, com isso, compreender a relação que se pauta entre as categorias de gênero e religião vista, historicamente, em conflito com as Ciências Sociais da Religião, pensando a sua inserção nas Ciências das Religiões. Sobre tal pretensão interpretativa, penso ser necessário alguns esclarecimentos introdutórios acerca do ponto de vista do qual escrevo:

Primeiro que, por mais que eu apresente, no decorre das sessões subsequentes, uma articulação bibliográfica conceitual e histórica, não estou interessado em fazer uma produção ou reprodução de fatos históricos. Minha intenção se caracteriza em fazer uma análise minimamente crítica, a partir de algumas posições e princípios científicos das Ciências Sociais da Religião sobre as análises de gênero, pautando a formação das Ciências das Religiões sobre este contexto, constatando a tímida inserção desses estudos.

Em segundo plano, vale lembrar que estou ciente dos riscos advindos das críticas de dois polos, seja dos conservadores das posições positivistas de pensar os estudos das religiões, seja das feministas com posições mais radicais que costumam não reconhecer as análises de gênero feitas por homens (sem perceber que reproduzem o mesmo determinismo biológico que fomenta construções sobre anatomia dos sexos). Mesmo sendo homossexual e estando numa condição militante muito próxima, sei dos riscos que corro, quando procuro escrever sobre o que me é familiar. Aliás, tendo a concordar com Gilberto Velho (1978), quando pensando os impasses entre objetividade e subjetividade do pesquisador, na pesquisa do que lhe é familiar, esclarece tais riscos.

\footnotetext{
Estou consciente de que se trata, no entanto, de uma interpretação e que por mais que tenha procurado reunir dados "verdadeiros" e "objetivos" sobre a vida daquele universo, a minha subjetividade está presente em todo o trabalho. Isso está claro para mim na medida em que volto constantemente a reexaminar a pesquisa e mesmo a revisar o local da investigação. [...]. Desta forma a minha interpretação está sendo constantemente testada, revista e confrontada. $\mathrm{O}$ mesmo não se dá com muitos estudos de sociedades exóticas e distantes, pesquisadas por apenas um investigador, em que não houve oportunidade de maiores discussões ou polêmicas. (grifos do autor, p. 43-44).
} 
Assim, por pensar que venho de uma formação em Ciências Sociais, com tendências muito fortes para a antropologia e a sociologia, não me sentiria confortável em fazer qualquer constituição histórica, a não ser para analisá-la. ${ }^{2}$

Em detrimento disso, penso as Ciências das Religiões sobre o ponto de vista das Ciências Sociais, pois estou tentado a refletir tais campos como concepções formativas de uma para a outra. Compreendendo as dificuldades históricas que enfrentavam as mulheres pesquisadoras no meio científico e pelas Ciências Sociais da Religião, como quase impenetráveis por elas. Indago, então, como se dá a inserção dos estudos de gênero pelas Ciências das Religiões, enfatizado o contexto no qual estou inserido. Com isso, no caminho que procuro seguir, trago alguns momentos reflexivos:

No primeiro momento, trago uma breve concepção formativa das Ciências das Religiões, enfatizando a discussão histórica sobre o conceito de religião e suas impossibilidades de definição universal. Supondo tal perspectiva, um ponto de proximidade com a própria formação às vezes singular, às vezes plural das Ciências das Religiões e as visões de seus criadores. Construindo, então, uma linha a partir das Ciências Sociais.

No segundo momento, busco questionar os estudos de gênero no cenário das Ciências Sociais da Religião, expondo a visão que marca a impossibilidade de entrelaçamento dos objetos. Pergunto, inclusive, se tal perspectiva se fundamenta na composição das Ciências das Religiões.

No terceiro, faço uma busca pelas personagens que se destacaram na produção e resistência dos estudos de gênero e religião no âmbito, antes tão masculino, como se caracterizou os estudos de religião. Além disso, apresento alguns de seus feitos que contribuem para falar-se da junção gênero e religião pelas Ciências das Religiões.

Esta pesquisa se caracteriza em uma conjuntura interdisciplinar que faz dialogar as Ciências Sociais da Religião, as Ciências das Religiões e os estudos de gênero e religião, numa tentativa de trazer à tona a importância das categorias citadas em suas relações históricas.

\footnotetext{
${ }^{2}$ Pois "é exatamente essa capacidade de olhar uma situação dos pontos de vistas de sistemas interpretativos antagônicos que constitui uma das características da consciência sociológica" (BERGER, 1986, p. 48).
} 


\section{A formação das Ciências das Religiões sobre um ponto de vista das Ciências Sociais}

Se aqui me dispus a fazer um pequeno e breve panorama sobre o percurso formativo das Ciências das Religiões no curso da história, sobre o ponto de vista das Ciências Sociais, talvez seja necessário que se comece pelo esclarecimento do que se toma por princípio norte destas correntes científicas, o seu objeto de estudos, a religião (ou as religiões).

Buscar a compreensão para uma significação geral do termo foi, e é até os dias atuais, um processo complexo e problemático, dentro da academia especializada (as Ciências Humanas) sobre seus estudos. E sobre a busca de sua definição (que se caracteriza em fatos e condições históricas e culturais), se manifestam as mais variadas vontades de reduzir o termo a uma significação universal e lógica. Uma busca incessante de encontrar qualquer condição que estabeleça conexão a todas as religiões. Tais perspectivas tendem a ser amplamente revistas e criticadas, pois o que parece é haver uma quase impossibilidade, se assim posso afirmar, de ascensão desse pensamento unificador. Haja vista que não existe, até então, algo que contemple todas as religiões institucionalizadas ou não. Pois é notório que as várias classificações se dão diferente para cada uma delas, quando se denominam como: religião, ou doutrina, ou mística, ou transcendência e etc.

É necessário levar em consideração que o termo religião é uma produção intelectual ocidental, mencionada várias vezes por autores com uma competência religiosa, a cristã. Klaus Hock (2010), no seu livro Introdução à Ciência da Religião, concebe no segundo capítulo, uma boa reflexão histórica e epistemológica do que e como se forma o termo religião. Em $O$ que é religião? $\mathrm{O}$ autor traça um percurso que discute as produções dos significados pertencentes à criação do termo. Sobre as bases do latim, religião seria para alguns autores (em especificidades os de formação cristã), uma ramificação do termo Religio, que teria como significado no latim a "atuação com cuidado" ou "observação cuidadosa". No romano, concebido por Cícero (autor pré-cristão), a definição se dá como "culto aos deuses", percebido por ele nas condições das ações em ritual, como forma de precisão, o ato de fazer correto. (HOCK, 2010, p. 17 e 18).

Numa visão sobre as bases ocidentais cristãs, o termo religião é para autores como Lactâncio e Agostinho uma derivação ainda do latim, Religio de Religare, que tinha como significação "ligar de volta", uma forma explicativa de relacionar a reconciliação do homem antes perdido com seu Deus salvador. (HOCK, 2010, p. 18). 
No período da reforma protestante, o termo religião se caracterizara sobre um sentido de crítica, em relação a ele se daria um significado antagônico, uma oposição a termos como magia e superstição, que se fundamentavam sobre o paganismo.

Com a reforma, "religião" se torna um termo que desempenha uma função crítica: contra "superstição" e "magia", mas também contra a atuação cúltica da Igreja Católica Romana em seus serviços divinos, que, aos olhos dos reformadores, era errada. Por outro lado, tem início uma tendência à generalização do termo religião que se impõe, aos poucos, com o Iluminismo. (HOCK, 2010, p. 19).

Tais convicções advindas de formações cristianizadas, tendem a mostrar a forma de dominação sobre essa única corrente religiosa. Isso se fazia presente, ao que me parece mostrar Klaus Hock (2010), até o período do Iluminismo quando se busca um sentido que pudesse ser visto como fator de serventia para todas as religiões (momento que se caracteriza no processo de desmistificação da religião, tendo como argumentação, ser ela uma produção da mente humana), mesmo partindo da hegemônica visão ocidental cristã. O problema se institui em levar o termo religião, nas mesmas condições, do ocidente para o oriente, o que não se assemelharia, ou melhor, algo que não se daria como reconhecido pelas culturas orientais.

\footnotetext{
Outras religiões expressam a própria autocompreensão recorrendo a termos ligados ao conceito de "caminho": p. ex., com a palavra rita, o hinduísmo antigo designava o fundamento do mundo, a ordem cósmica com a qual todos os seres devem estar afinados, e, sobretudo, a correta execução dos ritos realizados pelos brâmanes [...].No âmbito mesopotâmico, o termo gischar indicava, junto com rita do hinduísmo, a regra material e moral do mundo. No Egito, a palavra maat, expressa antropomorficamente pela deusa homônima - que, como reza um texto funerário, "jamais foi perturbada desde o dia em que foi criada" e "à qual se dirige todo o ocidente" - , encerra a doutrina fundamental, a ordem, a essência da existência, a justiça. (FILORAMO e PRANDI, 1999, 254 e 255).
}

As tentativas saem do período do Iluminismo e tomam os séculos XVII e XVIII, com autores que procuravam fazer análises das culturas, por eles ditas primitivas, relacionando as suas manifestações e cultos sobre as suas construções religiosas (cristãs e ocidentais). Esse período se caracteriza pelas análises de gabinete estabelecidas nos estudos das culturas primitivas e selvagens, reconhecidas no seio das teorias de Tylor, Morgan e Frazer, os chamados evolucionistas culturais. Com suas apropriações dos conceitos darwinistas, viam, sobre o ponto de vista da civilização, o mais alto estágio evoluído da vida humana (CASTRO, 2005). E, nessa escala, onde a civilização ocidental era a vida evoluída, as demais culturas seriam uma espécie de conjunto de seres em evolução, que passariam por todos os estágios até chegar à civilização. 
Em relação à religião, em sua maioria de análises feitas sobre as teorias evolucionistas, o comparativo partia do cristianismo. O que vem a influenciar as sucessoras pesquisas e pesquisadores da época, tendo em vista a ideia de que a religião cristã seria o mais alto estágio evolutivo, instituição competente da sociedade civilizada.

No século XIX, é possível perceber as primeiras tentativas de relativização e compreensão do termo religião sobre o olhar que se porta no pesquisador. Autores como Geertz $^{3}$, Durkheim e Mauss, entre outros, dentro do contexto das Ciências Sociais, tendem a fazer reflexões, principalmente metodológicas, sobre análises em religião. Partiriam sempre de um ponto conceitual (por eles organizado), muitas vezes primário do termo, o que mais tarde vem a ser verificado e constatado a influência positivista da generalização, como uma premissa a ser revista.

Em As formas elementares da religião (1912), Durkheim queria revelar os componentes que constituem todas as religiões, o aspecto basilar das religiões (a forma elementar). Pelo fato de a forma mais elementar da vida social deve abrigar a forma mais elementar de religião Durkheim seguiu a pista de Tylor e também apresentou o totemismo aborígine australiano como uma religião elementar, inclusive como "a religião mais primitiva e mais simples que é possível encontrar". (SCHMIDT, 2007, p. 65).

A problemática do conceito sobre uma definição universal é questionada também sobre duas concepções teórico/metodológicas que se estancam no seio da Antropologia, o funcionalismo cunhado sobre as teorias de Malinowski e Radcliffe-Brown e o estruturalismo de Lévi-Strauss e Franz Boas. Tais teorias visam buscar a relativização do olhar antropológico sobre o lugar de onde pesquisa o antropólogo, dando margem à discussão de que as religiões também precisavam ser vistas por suas particularidades culturais; funcionais no caso do modelo funcionalista, ou sobre as infraestruturas que constroem os fenômenos religiosos. As duas teorias, mesmo que divergente, contrariam o evolucionismo e partem do mesmo pressuposto, a construção teórica a partir da experiência com o campo e os sujeitos nele.

Com as novas ramificações de crenças (sejam de religiões institucionalizadas ou não), os novos movimentos religiosos, que nascem sobre os meados dos séculos XX e XXI, vieram confirmar essa necessidade, considerando os novos sentidos atribuídos do que é religião em cada contexto religioso.

${ }^{3}$ Geertz (1989) em A interpretação das culturas, esclarece sob seu ponto de vista, a ideia de análises de culturas religiosas partindo de um conceito previamente concebido, após a inserção do pesquisador na cultura. 
Em uma análise difícil de concretizar-se, acerca de uma conexão que a possa torná-la universal, assim como o termo religião, as Ciências das Religiões parece seguir de uma mesma construção histórica.

Vista pela primeira vez como proposta disciplinar nas discussões de Max Müller, a Ciência da Religião (no singular como assim concebia o autor) tratava-se de uma ciênciaque, através da linguagem, se consistiria o conhecimento das culturas, sobre o parâmetro das instituições religiosas, entendendo que seria mediante o rigor científico que se dariam os estudos das religiões sob o método comparativo. Tal princípio levantado por Müller traria como defesa que a comparação, em nível científico, se dá sobre a realização de não considerar superioridade entre qualquer religião.

Concebendo análise sobre o termo religare e, de certa forma, revisando e impugnando esse princípio, Müller pensara religião como uma palavra de sentidos múltiplos, concedidos através de tempos e espaços, ou seja, designado sobre uma forma cultural vista em épocas especificas e com significados que são produzidos sobre fatores condizentes com tais épocas. Concebia, ademais, que toda religião começaria de um mito e, com isso, explicaria que as religiões "apresenta o que sua cultura realmente dita, faz e informa". (REDYSON, 2016).

Müller foi só o princípio de uma terminologia para os estudos de religião, tendo em vista que sua base defensiva se dá sobre o caráter autônomo da ciência. Ciência da Religião, sobre uma compreensão singular, ressaltando haver características próprias e, por isso, merecida de um status científico próprio.

Apesar disso, é preciso argumentar que não existe um ponto de vista científico único sobre religião, considerando a interdisciplinaridade que se apropria do objeto de análise. As Ciências das Religiões se constituem de um rol de disciplinas que, historicamente, se interessam pelo objeto em vários aspectos e visões diferentes. Definindo como Ciência da Religião, sobre um ponto de vista metodológico específico (o comparativo), o filólogo e historiador da religião, Max Müller, talvez não tenha atentado para as demais formas de ver e pensar religião, sobre os mais vastos olhares.

Suas formulações no contexto de autonomia para a Ciência da Religião tendem a influenciar várias escolas de estudos de religião, dentre elas a alemã que repercute com a defesa até os dias atuais. No entanto, trate-se de uma defesa muito criticada, pois no cerne da discussão sobre sua nomenclatura, Ciência da Religião seria uma aproximação à Teologia, 
quando parece, com isso, defender que ela tem uma metodologia própria de análise e uma corrente religiosa específica. Tal noção não contempla as demais ciências e seus diferenciados métodos, assim como a multiplicidade de religiões, doutrinas, crenças, entre outros, que institui modos de vida, ações, comportamentos, em nível individual e coletivo.

Correntes científicas se estabelecem sobre a defesa interdisciplinar que define as Ciências das Religiões (no plural), visando o reconhecimento e validade dos estudos feitos sobre religião, isto nas mais várias disciplinas. Em um diálogo que quebra com as barreiras estabelecidas pelas ciências tradicionais, criando um compartilhamento de teorias e métodos.

Para algumas dessas ciências, o objeto religião tende a ser um objeto de análise muito caro, a título de exemplo: a psicologia e os estudos dos impactos que a religião causa sobre o sujeito cognitivo, suas ações, comportamentos e emoções, como sobre o coletivo. Para antropologia, nas minuciosas análises das instituições como promotora de padrões, símbolos, signos e significados que fundamentam os modos de vida em cada cultura e como parte delas. Como para a sociologia que, de acordo com Maria José Rosado Nunes (2007), talvez a sociologia tenha seu início na sociologia da religião.

Desde o seu início, a sociologia interessa-se pela religião. Poder-se-ia mesmo dizer que, no limite, nasce como sociologia da religião, na medida em que, ao se propor entender a sociedade de maneira científica, a sociologia confronta-se imediatamente com o fato religioso. (p. 102).

Essas disciplinas, com mais uma gama de ciências, propendem a produzir pesquisas com análises no objeto religião. Logo, métodos e abordagens teóricas vêm sendo, historicamente, produzidos no universo acadêmico sobre o tema, não fazendo muito sentido a redução a autonomia, por um único método e abordagem.

No Brasil, no seio dos programas de pós-graduação ainda há certa divisão de defesas, que sai de Ciência da Religião de forma autônoma e singular, passa por Ciências da Religião até Ciências das Religiões, formas plurais reconhecedoras das demais disciplinas. Essas duas últimas buscam explicar a institucionalização das Ciências das Religiões como campo inter/trans/multidisciplinar ${ }^{4}$. Para Marcelo Camurça (2008) a Ciências da Religião se evidencia mais como um campo disciplinar que reúne pesquisas de vários campos científicos sobre um único objeto, a religião.

\footnotetext{
${ }^{4}$ As palavras importam muito e, ao mesmo tempo, pouco. No caso de multi, inter e transdisciplinaridade, cada um desses termos tem uma contribuição a dar, mas nenhum se basta. O importante mesmo é a atitude epistemológica. A interdisciplinaridade junta disciplinas diferentes; a multidisciplinaridade, articula-as; só a transdisciplinaridade, porém, supera a particularidade, conjuga os saberes e faz com que aportes diferentes trabalhem por um mesmo fim. (SILVA, 2007, p. 33).
} 
Considero que o campo de Ciência(s) da Religião deva estar sintonizado com os debates, impasses e avanços teórico-metodológico que estão-se dando nas respectivas instâncias de cada ciência humana e social, da qual religião é, junto com outras, mais uma subárea; como também que do campo de Ciência(s) da Religião possam surgir novas teorias e contribuições, todavia sempre em interface com as grandes disciplinas e ciências. (grifos do autor, p. 27).

Assim como as Ciências das Religiões, é possível pensar o caráter dos estudos feministas e de gênero como um campo interdisciplinar, intentando as relações de gênero como objeto de interesse das demais ciências. Mas como pensar os dois campos em interrelação? Não é difícil, pois, na maioria de abordagens, as ciências que dominam as pesquisas sobre os dois objetos estão inscritas nas ciências humanas e sociais. Entretanto, a relação histórica dos objetos de pesquisa nem sempre foram bem vistas, assim como a inserção da mulher no universo científico. Nos estudos de religião, há uma constituição memorável predominantemente masculina.

Dentro dos campos ao qual me compete uma relação de estudos (as Ciências Sociais), tento esclarecer que, por mais que se tenha (esse campo científico) certo domínio específico sobre os objetos, ele não conseguiu se mostrar com bons exemplos no que me refiro às análises, principalmente do feminismo para com a religião, que, por vezes, foram elas deslegitimadas pelas disciplinas que a compõe. A relação, principalmente da Sociologia da Religião com o feminismo e os estudos de gênero, não foram bem vistas. De acordo com Maria José Rosado:

Da parte da abordagem sociológica das religiões, o feminismo, enquanto proposta de análise, não existia. Parecia academicamente impróprio interrogar a realidade religiosa do ponto de vista das diferenças colocadas pelas relações sociais estabelecidas entre os sexos. Assim, abordar sociologicamente o tema religião, perguntando pelas mulheres, do ponto de vista da crítica feminista, era como andar sem bússola pelo deserto. (2001, p.79-80).

A abordagem feminista, que tem muitas vezes bases no marxismo ${ }^{5}$ e sua forma de pensar ciência, não reconhece a neutralidade como fator a ser levado em conta na pesquisa científica, justificando que todo sujeito se insere de valores produzidos por condições de bases culturais ${ }^{6}$. A Sociologia da Religião, pautada em grande parte sobre positivismo, difere-se dessa suposição cobrando distanciamento, neutralidade e imparcialidade nas pesquisas em religião. Por tais supostos que compõe as visões aqui mencionadas, surgem questões e críticas, certo embate que fomenta a discussão.

\footnotetext{
${ }^{5}$ Sobre esta afirmação, sigo os fundamentos do que levantou Andery (1988), em seu livro, Para compreender a ciência, trazendo várias vertentes epistemológicas de visões científicas, dentre elas o autor traz as posições marxistas que, em suma, diverge do positivismo sobre as concepções de neutralidade científica.

${ }^{6}$ Ao fazer essa afirmação, estou embasado sobre as leituras Lucila Scavone (2008), sobre a constituição da sociologia do gênero, sobre a qual estabelece várias perspectivas de estudos feministas nas bases da sociologia.
} 
Buscarei destacar agora as Ciências Sociais da Religião, pois, por estar inserido neste espaço, me condiciono a perceber esse campo do saber como responsável pelas primeiras críticas e embates no que concerne aos estudos de gênero relacionados à religião.

\section{Ciências Sociais da Religião e os estudos de gênero e feministas: constituições, críticas e embates}

Dentro da área que firma as Ciências Sociais, as disciplinas que mais se debruçam sobre os estudos das religiões são, Antropologia e Sociologia. Com correntes de pensamentos bem específicas e diferenciadas sobre métodos e abordagens teóricas. De acordo com Rosado Nunes (2010), as disciplinas se caracterizam baseadas nos instrumentos que partem dos pais fundadores das Ciências Sociais, enfatizando Durkheim e Weber ${ }^{7}$.

No que tange à relação com os estudos de gênero, a Sociologia sobre as bases teóricas da Sociologia da Religião, não se caracteriza como campo reflexivo que contribui com a relação estudos de gênero e religião. Há que se considerar que,tais estudos foram vistos pela Sociologia da Religião como algo inapropriado e inconcebível, deslegitimado sobre o ponto de vista positivista (ROSADO NUNES, 2010).

Essas concepções positivistas cobram do pesquisador um posicionamento neutro, distanciado, fora do campo religioso. Logo, caracterizavam os estudos feministas como distante dos padrões de pesquisa, por trazerem um caráter reivindicatório, o que fazia com que perdesse a neutralidade prevista.

Para as feministas, esse interesse político seria uma base consistente discursiva para quebrar com esse paradigma positivista. Não se poderia atribuir às relações de gênero como "coisa" valores. São as feministas grandes críticas da Sociologia da Religião, pois viam nas suas clássicas teorias, a reprodução da desigualdade social de gênero, tanto no campo do fazer científico, como no discurso religioso (ROSADO NUNES, 2010).

\footnotetext{
${ }^{7}$ Dentre os três autores considerados pais das Ciências Sociais, Karl Marx não se constituiria como um sociólogo da religião. O mesmo via o objeto como "uma realidade histórica dependente do desenvolvimento das condições materiais de vida e da consciência dos indivíduos. Para Marx, a religião desaparecerá, dada a evolução dos processos históricos e das consciências individuais.” (ROSADO NUNES, 2010, p. 105).

${ }^{8}$ Teoria durkheimiana que se refere às análises dos fatos sociais com a necessidade de vê-los como "coisas", objetos concretos, mas estranhos aos olhos do pesquisador. Ver: Durkheim, E. As regras do método sociológico.
} 
A crítica das religiões foi feita no plano político e militante. As religiões foram tratadas como instrumentos dos mais eficazes para o controle das mulheres e para a manutenção de sua subordinação social e religiosa. (ROSADO NUNES, 2010, p. $111)$.

Os estudos de gênero estão localizados muito mais na antropologia, se se considerar que uma das primeiras aparições de análise de gênero se dá nas bases do estruturalismo de Margaret Mead, em basicamente duas obras Sexo e temperamento em três sociedades primitivas e Masculino e Feminino (SCAVONE, 2008). Ainda assim, sobre o pensar antropológico, as concepções que se volta sobre as categorias de gênero e religião, pareciam em suas obras, ainda secundárias. Elas foram vistas sobre posições analíticas mais direcionadas para os mitos que compunha as culturas indígenas, feitio que interessava a antropologia da época. Ou seja, as questões se estruturavam no pensar os costumes dos povos estudados, fazendo, assim, menção ao modo de vida da mulher naquela cultura.

Neste sentido, talvez me seja possível afirmar que, por mais que o campo das Ciências Sociais tivesse certo domínio sobre os objetos, gênero e religião, os estudos em específico, não existiram por um longo período de tempo, pois "parecia academicamente impróprio interrogar a realidade religiosa do ponto de vista das diferenças pelas relações sociais estabelecidas entre os sexos" (ROSADO, 2001, p. 80).

Por bastante tempo, os acadêmicos do campo dos estudos religiosos negligenciaram
o papel da mulher e, particularmente, a religião como meio de atribuição de poder
para as mulheres. Até recentemente, bem poucos acadêmicos dos estudos religiosos
consideravam o gênero a ser trabalhada em sua pesquisa. (SCHMIDT, 2010, p.88).

Para falar de datas e marcos históricos, concernentes às produções da soma nos estudos científicos entre religião e gênero, é necessário ressaltar a Teologia, ou melhor, as teólogas feministas do século XX e XXI, como responsáveis pelos primeiros impulsos que instigam o cruzamento dos temas.

Com o advento da revolução feminista, mas especificamente da segunda onda que marca meados dos anos de 1960, nasce uma nova concepção teológica criada por mulheres: a Teologia Feminista (SOUZA, 2008).

A Teologia Feminista é constituída sobre a influência dos estudos feministas e das análises e métodos que criticavam as posições de desigualdade social entre o homem e a mulher. Essa revolução causou grandes impactos sobre as ciências masculinizadas, reivindicando espaço e legitimidade às mulheres no âmbito científico, que tentavam trazer à tona algumas demandas. 
Essas passam a reivindicar uma ampliação do campo de investigação científica, da metodologia tradicional e dos marcos conceituais clássicos, e assim, a vida privada é trazida a público, particularmente pelas mãos das mulheres. (SOUZA, 2008, p. 18).

Nesse contexto, buscam questionar o poderio masculino sobre as ciências, demarcando espaços e criticando os modos teórico/metodológicos tradicionais de análises, pautando sobre a pesquisa com a vida humana e suas relações. Levantam-se para reivindicar a inserção de uma análise da vida privada da mulher, juntas a várias disciplinas (antropologia, sociologia, psicologia, filosofia, teologia entre outras) mulheres com formações acadêmicas nas diversas áreas.

Reconhecendo-se nestes espaços de produções científicas, e agora questionadas pelas teorias feministas, as teólogas tentavam rastrear e compreender, inicialmente, a busca das mulheres pela fé cristã, fazendo com isso críticas às instituições religiosas sobre a sua submissão perante os regimes machistas e patriarcais.

Como afirma Maria José do Rosado (2001), ainda entre os séculos XX e XXI, houve grande período de silêncio na produção científica sobre gênero e religião, até mesmo pelas feministas. Esse período vai desde a publicação de The Woman's Bible, que contava sobre uma interpretação bíblica feminista, até Mary Daly, nos anos 1960, que produziu uma obra baseada nas análises de Simone de Beauvoir, The Churchand the Second Sex, com o intuito revolucionário de impactar as instituições cristãs, na qual fazia também parte a autora. Tentativa que foi frustrada e reconhecida em publicações subsequentes.

No Brasil, os dados históricos sobre a publicação, tanto dos estudos de religião como dos estudos de gênero, tiveram grande ênfase em um mesmo período que marca um percurso de acessão desses objetos, a década de 1970. No entanto, aqui no Brasil essa relação se organiza timidamente. De acordo com Sandra Duarte de Souza (2004):

Os estudos sobre religião no país começam a superar os limites da mera história eclesiástica somente a partir da década de 70 , quando uma certa organicidade, entre estudiosos da religião e instituições religiosas começam a ceder lugar a uma nova maneira de compreender o fenômeno. (p. 122).

É importante ressaltar que é nesse período em que surge também no Brasil a Teologia Feminista, concomitante e apoiada ao surgimento dos movimentos sociais e da Teologia da Libertação, num período de repressão histórica da política do país, a ditadura militar. Mesmo não tendo tanta visibilidade, no que concerne ao interesse dos estudos feministas que era sobre a atuação da mulher no meio político e, por já se pautar um pensamento sobre a secularização da religião, ou seja, não sendo ela mais uma instituição provedora e 
determinante da vida humana, as primeiras obras sobre os estudos de gênero e feminismo no berço brasileiro dormem nesse período (SOUZA, 2008).

Uma grande personagem desses estudos é a teóloga feminista Ivone Gebara, que produziu todo um arcabouço histórico e analítico sobre mulheres e suas inserções em instituições religiosas.

Ivone Gebara, religiosa da Congregação das Irmãs de Nossa Senhora Cônegas de Santo Agostinho, doutora em Filosofia e Ciências Religiosas. Ela é uma das expoentes da Teologia Feminista (TF) brasileira. Filha de pais imigrantes libaneses e sírios, com 22 anos entrou para o convento, nos anos da efervescência daquela que foi chamada a "opção pelos pobres" da Igreja Católica. Morando em Recife, participou intensamente, ao lado de Dom Hélder Câmara, da organização das Comunidades Eclesiais de Base e da elaboração da Teologia da Libertação (TL). (ROSADO-NUNES, 2006, p. 295).

As bases de seus estudos se relacionam a princípios já vistos sobre o corpo feminino. Para a teóloga, não se faz Teologia Feminista se não partir do corpo, pois é através dele que se garante uma gama de produções discursivas que moldam comportamentos, ações e constituições sociais sobre a mulher. É o determinismo biológico, a anatomia do corpo, produtora dos discursos que marcam as construções sociais de divisão desigual de trabalho e a dominação masculina.

Fazendo uma reflexão sobre as teorias e análises fundamentadas e dadas pelas teólogas, que buscavam de forma crítica respostas das expressões religiosas sobre a repercussão da dominação masculina nessas instituições e a injusta divisão social do trabalho. Penso se tais perspectivas não seriam um desafio para as Ciências Sociais da Religião hoje, considerando sua tradição na rigidez científica? Sandra Duarte de Souza (2008) vem nortear uma resposta:

\begin{abstract}
Os estudos de gênero ainda buscam legitimidade no contexto das Ciências Sociais em geral, porém, é no campo especifico dos estudos de religião que a marginalidade de gênero enquanto categoria analítica faz visível, denunciando uma "presença acessória" dessa categoria nesse universo.

A incorporação dos estudos de gênero como categoria analítica nos estudos de religião é ainda recente no Brasil. A resistência nesse campo de estudos é a mesma que se encontra em outras áreas de pesquisas, uma vez que os paradigmas científicos baseados em uma noção generificada do saber influenciam a escolha das fontes, dos interlocutores, do quadro teórico e do próprio objeto a ser pesquisado. (p.21-22).
\end{abstract}

Para a autora, o desafio problematiza a área e o que por ela foi feito. Pois, no Brasil, as produções em Sociologia da Religião, principalmente dos anos de 1950 a 1970, não são especificamente perspectivas sociológicas da religião. O que se tem, se caracteriza muito mais como uma sociologia religiosa, feitas por homens e voltadas à promoção de instituições 
religiosas. Sobre esse contexto são homens, líderes religiosos, produtores do conhecimento sobre sociologia da religião e, assim, representantes deles.

Portanto, o que precisa ser levado em conta é que tal silenciamento das Ciências Sociais da Religião, sobre a equação gênero e religião, deixa se perder na inebriada autoridade científica, perguntas jamais feitas por esse campo. Pois, é obvio que as religiões tendem a inferir diretamente nos significados de gênero, produzindo e reinventando culturas e relações sociais promotoras de desigualdades, dominação e relações de poder de um gênero sobre o outro.

Sendo as Ciências Sociais da Religião uma área indispensável para as Ciências das Religiões, correspondente a disciplinas determinantes nas análises dos fenômenos religiosos, pergunto-me se esse engessamento tradicional histórico das Ciências Sociais da Religião também se fez, ou faz parte do contexto formativo das Ciências das Religiões, enquanto campo tão jovem, pelo menos no Brasil?

Na busca de respostas para esta questão, debruço-me a pensar sobre como se concebe a inserção dos estudos de gênero nos programas de pós-graduação em Ciências das Religiões no país. Considerando a busca de alguns personagens, periódicos, grupos de estudos, linhas de pesquisas, instituições de fomento e etc., que deram margem a discutir a equação gênero e religião.

\section{Um olhar sobre a inserção dos estudos de gênero nas Ciências das Religiões.}

O lugar do feminismo e dos estudos de gênero na ciência, durante muito tempo, passou por questionamentos e desconfianças, sendo, por várias vezes, deslegitimadas, provindo de posições que demonstravam a superioridade masculina nas suas instâncias, tomando as posições femininas como secundárias e de pouco importância. Longe ainda de terse demolido as construções sociais de desigualdade diante das condições de sexo, o feminismo e os estudos de gênero tem contribuído de forma impactante na busca do reconhecimento feminino e suas produções e análises no mundo científico.

Tais produções têm-se direcionado para todos os âmbitos disciplinares,compreendidos dentro dos discursos que caracterizam, definem, qualificam, inventam, reinventam, constroem condições de ser mulher e ser homem. Desde as hipóteses do discurso biológico e da genética, até os mais sensíveis estudos das ciências sociais, sobre a forma de se pensar a identidade e a pertença em algum gênero. 
Assim como a religião, gênero ${ }^{9}$ se tornou um objeto de análise inter/trans/multidisciplinar que busca problematizar as relações sociais estabelecidas, produtoras das condições de comportamentos, ações individuais e coletivas, das relações humanas determinadas pelo sexo. Sob tal contingência, penso estar lidando com dois objetos de análises caros para Ciências Humanas. Diante do fato constatável hoje, na quantidade de estudos feitos sobre os temas nos mais variados campos disciplinares (FREIRE, 2015).

Contudo, há que se considerar que essa realidade não corresponde à relação existente no entrecruzamento dos dois objetos, os quais, ainda hoje, talvez seja possível afirmar que seja ele um tanto escasso e muito tímido. Indiferenças científicas/ideológicas que se desenrolaram no tempo sobre as discussões entre os dois objetos e os seus responsáveis, podem dar ênfase a essa escassez.

No Brasil, essa realidade é ainda muito presente, apesar de já estarmos caminhando para alguma ascensão. Já se encontra no universo acadêmico, boa contribuição que parte dos anos de 1970 aos dias atuais. São pesquisas que nascem no seio das pós-graduações que se concebem dentro das Ciências Humanas e Sociais, estabelecendo e problematizando os dois objetos em olhares inter/trans/multidisciplinares.

Por muitas vezes, os estudos publicados trazem uma interpretação socioantropológica, considerando o que caracteriza a visão das Ciências Sociais nas suas formas de abordagem teóricas e metodológicas. As peculiaridades dessas ciências são bem salientadas nas palavras de Peter Berger:

A perspectiva sociológica pode então ser compreendida em termos de uma frase
coloquial como "olhar por trás dos bastidores". [...] Não estaremos muito distantes
da verdade se virmos o pensamento sociológico como parte daquilo a que Nietzsche
chamou de "a arte da desconfiança". [...] a perspectiva sociológica envolve um
processo de ver além das fachadas das estruturas sociais. (1986, p. 40-41).

No Brasil, sobre o ponto de vista dos estudos de gênero e das teorias feministas, duas importantes contribuições nascem de periódicos acadêmicos. Duas revistas científicas interessadas exclusivamente sobre os estudos de gênero e sexualidades nos mais variados enfoques, a Cadernos Pagu da Universidade Estadual de Campinas - UNICAMP e a revistas Estudos Feministas que seria originalmente da Universidade Federal do Rio de Janeiro -

\footnotetext{
${ }^{9}$ Em certa medida, talvez gênero, enquanto perspectiva de análise, também tenha pedido sua autonomia, quando Scott em seu artigo Gênero: uma categoria útil de análise histórica, propõe pensar gênero por uma perspectiva metodológica própria de análise. No entanto, a autonomia enquanto área e disciplina não aparecem em sua história.
} 
UFRJ passa a ser em 1999, uma publicação da Universidade Federal de Santa Catarina UFSC (SOUZA, 2004).

Ambas as revistas procuram comunicar os mais diversos estudos que se correlacionam às categorias de gênero e sexualidade. No entanto, de acordo com Sandra Duarte de Souza (2004),as publicações sobre esses e a temática religião não parecem tão significativa e, muitas vezes, incidem ser secundárias, aparecendo somente questões como: religiosas afrobrasileiras, moral sexual religiosa, discussões sobre o aborto entre outros poucos temas.

Seria, então, sobre o berço das Ciências das Religiões que nasceria o primeiro periódico exclusivo para produções contendo as temáticas, a revista Mandrágora ${ }^{10}$.

\begin{abstract}
A Revista Mandrágora surgiu provocada justamente por essas questões. A transversalidade do gênero obriga-nos à discussão do objeto religioso. "As pesquisas baseadas no eixo gênero e religião se justificam pelo simples fato de que existe aí uma intimidade pouco verbalizada, mas experimentada, vivenciada no habitus social, que é estruturado e que estrutura a vida em sociedade. Revelar essa intimidade é revelar também a cumplicidade da religião sobre o processo de socialização de homens e mulheres, e de reprodução das assimetrias sociais. (SOUZA, grifo da autora, 2004, p. 124).
\end{abstract}

A revista se idealiza em uma iniciativa de pesquisadoras alunas do programa de pósgraduação em Ciências da Religião do antigo Instituto Metodista de Ensino Superior - IMS, hoje conhecido como Universidade Metodista de São Paulo - UMESP. Mulheres, ativistas e pesquisadoras vinculadas ao Núcleo de Estudos Teológicos da Mulher da América Latina NETMAL, tinham por interesse e objetivo instituir uma revista que se esforçasse na contribuição acadêmica sobre a equação gênero e religião, produzindo textos para a academia e os movimentos sociais (SOUZA, 2004).

A revista Mandrágora é uma produção que demonstra várias noções sobre suas criadoras, pois, além de conteúdos acadêmicos, ela traz o espírito de resistência dessas mulheres, quando as mesmas se encontram em uma instituição particular e confessional. A revista torna-se emblemática, quando vem tratar das questões de gênero e religião em um ambiente até então tomado por homens, como é o das Ciências das Religiões e sua representatividade brasileira.

\footnotetext{
${ }^{10}$ Muito nova, com apenas quatro edições lançadas, existe também à revista Coisas do Gênero da Faculdade EST, que se caracteriza por uma revista de estudos feministas de gênero e religião. Porém, sua primeira edição é de 2015, já revista Mandrágora data de 1994. A Coisas de Gênero é vinculada a um programa de pós-graduação em Teologia, o que não interessaria pelo recorte que trago, ou seja, a área das Ciências da Religiões.
} 
A revista é somente uma entre as demais conquistas na área de suas pós-graduações. Refiro-me aos frutos que brotam através da resistência de pesquisadoras e professoras que se destacam ao longo do enraizamento das Ciências das Religiões no país. É necessário ressaltar algumas delas, como a Assistente Social, doutora em Ciências das Religiões, Sandra Duarte de Souza, professora da UMESP, coordenadora da revista Mandrágora e membro do NETMAL. Na matriz curricular do curso, a mesma aparece ofertando disciplinas optativas sobre religião e gênero, sendo também coordenadora de um grupo de estudos na mesma linha.

Na Pontifica Universidade Católica de São Paulo - PUC-SP, destaca-se nos estudos de gênero e religião, a professora Maria José Rosado Nunes, que é líder do grupo de estudos em gênero, religião e política, tendo como vice-líder a professora Paula Leonardi da Universidade de São Paulo - USP.

Outro nome de destaque no envolvimento dos objetos é a professora Fernanda Lemos, com sua carreira acadêmica feita na UMESP, tornou-se editora da Mandrágora e membro da NETMAL. Hoje, professora adjunta da Universidade Federal da Paraíba - UFPB, é coordenadora da graduação (licenciatura e bacharelado) em Ciências das Religiões, atua no programa de pós-graduação em Ciências das Religiões, onde é líder coordenadora do grupo SOCIUS - Grupo de estudos socioantropológicos de religião e de gênero.

Em outros contextos de pós-graduação em Ciências das Religiões, as temáticas não aparecem tão especificamente, como nos casos em que se destacam essas personagens que fazem história pela sua atuação, onde instituem linhas de pensamentos que dão espaço para a chegada de mais pesquisadores e pesquisadoras. Mas, costumam aparecer nas entrelinhas de grupos como de: Religiões, identidades e diálogos da Universidade Católica de Pernambuco UNICAP e em disciplinas obrigatórias, como é no caso do doutorado da PUC de Minas Gerais, que oferece a disciplina de Gênero e Religião.

Em um universo nitidamente masculino, pode-se entender que os estudos entrelaçando as temáticas constituem-se de lutas e resistências de poucas pesquisadoras. O que existia seria para elas uma vontade de mostrar e reivindicar a influência que exercer as religiões sobre as relações sociais de gênero. Poucas ainda são elas, nesse masculino campo dos estudos de religião (mas já conseguem ser significativas para o entrecruzamento dos objetos), a exemplo do que falo, fico tentado fazer uma análise das duas instituições que reúnem tais pesquisadores e pesquisadoras no país, a Sociedade de Teologia e Ciência da Religião SOTER e a Associação Nacional de Pós-Graduações em Teologia e Ciências da Religião - 
ANPTECRE e suas comissões diretoras, que vêm se compondo com, entre uma ou duas mulheres, cargos de alto nível.

Na SOTER, destacam-se Maria Clara Lucchetti Bingemer professora da PUC do Rio de Janeiro, onde já ocupou o cargo de vice-presidente da instituição e a professora Solange Maria do Carmo da PUC-MG, que ocupou o cargo de segunda secretária.

Na ANPTECRE, durante alguns anos, o poderio no diretório era masculino. Pela primeira vez, no ano de 2016, uma mulher tornou-se membro do conselho diretor, a professora Fernanda Lemos - UFPB, que assumiu o cargo de secretária do conselho diretor. Nos demais conselhos, e em gestões diferentes, aparecem os nomes das professoras Dilaine Soares Sampaio - UFPB, a qual ocupa cargo no conselho científico e a professora Maria Clara Lucchetti Bingemer-PUC-RJ, que também já ocupou o conselho científico.

As duas instituições promovem eventos nas áreas e, hoje, já se encontram em várias edições destes, grupos de trabalhos e palestras com a relação os objetos e seus cruzamentos. São vistos também nos mais variados eventos de gênero e sexualidade que acontecem no país, ao se destacar, o Seminário Nacional Enlaçando Sexualidades, o Fazendo Gênero e o Desfazendo Gênero, como também o internacional Latino Americano de Gênero e Religião que foi sediado no Brasil, pela última vez em 2015, em São Leopoldo-RS na Faculdade EST.

Contudo, como se pode perceber, a inserção dos estudos de gênero nas Ciências das Religiões se mostra um tanto tímida, mas muito resistente. Trata-se de uma jovem perspectiva de pesquisa que, durante tempos, esteve submissa às produções masculinas e, muitas vezes, interessadas a instituições religiosas. A resistência e persistência das pesquisadoras alongam um espaço de diálogo, discussão e atuação de mulheres no mundo acadêmico, principalmente sobre o hegemônico masculino campo de estudos de religião. Abriram caminhos para novos pesquisadores e pesquisadoras, clareando, no contexto interdisciplinar das Ciências das Religiões, as várias possibilidades de fazer pesquisa em gênero e religião.

\section{Considerações Finais}

Historicamente, tanto o termo religião como a constituição das Ciências das Religiões sofreu com problemas de definição conceitual. A religião, enquanto apropriação de seu significado e as Ciências das Religiões, enquanto disciplina ou área acadêmica. Tais 
problemas só mostraram a pluralidade do termo, assim como da área, que tem se concebido muito mais sobre composições interdisciplinares, possibilitando uma visão múltipla do objeto religião por várias ciências.

As Ciências Sociais, neste contexto formativo, têm grande influência por tomar a religião um objeto caro nas análises das relações sociais e culturais. Tendo, muitas vezes, a formação de campos científicos com abordagens teórico/metodológicas começando por sua análise do fenômeno religioso, como parece ser o caso da sociologia da religião. No entanto, como toda ciência, as Ciências Sociais da Religião passa por momentos históricos de aperfeiçoamento de suas abordagens teóricas e metodológicas, que determinam seus campos e análises, são exemplos: o evolucionismo, o positivismo, o funcionalismo, o estruturalismo, entre outros que se articula em paralelo. Cada uma traz visões específicas de como pensar as investigações em religião.

Neste cenário, o positivismo teve grande força no pensamento dos procedimentos metodológicos sobre o objeto religião. Ao ver a religião como "coisa", fato social a ser desvendado, cobrava do pesquisador posições neutras, distanciadas e imparciais. Essas perspectivas influenciaram tanto a antropologia das religiões, como a sociologia da religião, se caracterizando como uma abordagem que impregna concepções até hoje, a exemplo as ciências jurídicas entre outras.

Por durante anos de pesquisas, a abordagem positivista constituiu um pensamento tradicional para as Ciências Sociais da Religião. Sobre essas bases, não reconhecia, por vezes, pesquisas que trouxessem qualquer traço de subjetividade, como as análises feministas, que se enfatizava por um tom político e interessado.

As feministas carregando consigo uma abordagem mais marxista de pensar ciência, contrariavam as perspectivas positivistas, enfatizando a subjetividade do pesquisador presente em qualquer pesquisa, desde que é ele/ela sujeito social de valores produzidos por um contexto cultural. Foram elas grandes críticas ao modelo positivista, principalmente no contexto religioso. Pois trariam uma demanda específica, vendo na religião um fator cultural que massificava a ideia de submissão e obediência feminina nas formações patriarcais do sistema cristão.

Foi por tais embates (que precisou de uma revolução da mulher, buscando a garantia de seu espaço até no meio científico), que se deu a inserção dos estudos de gênero, com muita 
resistência das ciências tradicionais e masculinizadas. No que concerne aos estudos de gênero e religião, suas produções se dão timidamente, sem muitas repercussões. E mesmo sendo as Ciências Sociais, grande expoente nos estudos dos dois objetos, ao se tratar das categorias em interligação, seria inapropriado falar-se deles. As primeiras produções nascem do berço da teologia, uma teologia diferenciada, feita por mulheres, a teologia feminista.

No Brasil, a inserção dos estudos de gênero e religião ganha força no momento pósditadura, em que as teólogas feministas ganham apoio dos movimentos sociais e da teologia da libertação. Entretanto, as produções ainda pareciam de questionamentos muitas vezes secundários, para além de terem sido, essas teólogas, grandes questionadoras do sistema religioso cristão da época. Talvez para a área em formação das Ciências das Religiões a teologia feminista tenha melhor contribuição.

Para as Ciências das Religiões no Brasil, as pesquisas se dão acanhadamente, envergonhada e muito devagar. Sob o modelo singular, autônomo, a Ciência da Religião, parecia impossível de pensar as questões de gênero. Com muita resistência ao ambiente masculinizado dos estudos de religião, mulheres se levantam inserindo,de maneira alheatória, os estudos de gênero e feministas nas formas interdisciplinares da área das Ciências das Religiões no Brasil. Nomes como os de Maria do Rosado Nunes, Sandra Duarte de Souza, Fernanda Lemos, entre outras têm feito história nos campos das Ciências das Religiões no país. São mulheres que provocam a área com publicações, consagrando grupos de estudos, revistas científicas, disciplinas, entre outros procedimentos acadêmicos, dando oportunidade e voz a novas pesquisas sobre os objetos nas Ciências das Religiões.

\section{Referências}

ANDERY, M. A. Et al. Para compreender a ciência. Rio de Janeiro: Espaço e Tempo; São Paulo: EDUC, 1988.

BERGER, Peter.Perspectivas Sociológicas: uma visão humanista. Petrópolis: Editora Vozes, 1986.

CAMURÇA, Marcelo.Ciências Sociais e Ciências da Religião: polêmicas e interlocuções. $1^{\circ}$ ed. São Paulo: Paulinas Editora, 2008.

CASTRO, Celso.Evolucionismo Cultural: textos de Morgan, Tylor e Frazer. Rio do Janeiro: Zahar, 2005. 
DURKHEIM, Émile. As regras do método sociológico. Trad.: Paulo Neves: ver. de trad.: Eduardo Brandão. $3^{\circ}$ ed. São Paulo: Martins Fontes, 2007.

FILORAMO, Giovanni; PRANDI, Carlos. As Ciências Das Religiões. São Paulo: Loyola, 1999.

FREIRE, Ana Ester. P. Epistemologia Feminista: contribuições para o estudo do fenômeno religioso. Paralellus, v. 6, n. 13, jul-dez, 2015.

GEERTZ, Clifford. A interpretação das culturas. Rio de Janeiro: LTC, 1989.

HOCK, Klaus. Introdução a Ciência da Religião. São Paulo: Editora Loyola, 2010.

REDYSON, Deyve, Max Müller e o surgimento da Ciência da Religião (Religionswissenschaft) interpretações retidas da obra: MÜLLER, Max. La Ciencia de la Religion. Origem y desarrollo de la religion. Buenos Aires. Editora Alabastro, 2016.

ROSADO NUNES, Maria José. A sociologia da religião. In: USARSKI, Frank. (Org.). $O$ espectro disciplinar da Ciência da Religião. São Paulo: Paulinas Editora, 2007.

ROSADO NUNES, Maria José.Teologia Feminista e a crítica da razão religiosa patriarcal: entrevista com Ivone Gebara. Estudos Feministas, Florianópolis, v. 14, n. 1, jan-abr, 2006.

ROSADO, Maria José.O impacto do feminismo sobre o estudo das religiões.Cadernos Pagu, ed. 16, ago-dez, 2001.

SCAVONE, Lucila. Estudos de Gênero: uma sociologia feminista?.Estudos Feministas, Florianópolis, v. 16, n. 1, jan-abr, 2008.

SCHMIDT, Bettina E.A antropologia da religião. In: USARSKI, F. (Org.). O espectro disciplinar da Ciência da Religião. São Paulo: Paulinas Editora, 2007.

SCOTT, Joan. Gênero: uma categoria útil de análise histórica. Educação e Realidade, Porto Alegre, v. 20, n. 2, p. 71-99, jul/dez, 1995.

SILVA, Juremi Machado. Inter, Multi ou Transdisciplinariedade, uma questão de comunicação. In: MOTOSINI, Marília. Costa. (Org.). Inovação e Interdisciplinaridade na universidade. Porto Alegre: EDIPUCRS, 2007.

SOUZA, Sandra Duarte. A relação entre religião e gênero como um desafio para a sociologia da religião. Revista Caminhos, Goiânia, v. 6, n. 1, jan-jun, 2008.

SOUZA, Sandra Duarte. Revista Mandrágora: gênero e religião nos estudos feministas. Estudos Feministas, Florianópolis, v. 12, set-dez, 2004.

VELHO, Gilberto. Observando o familiar. In: NUNES, E. de O. (Org.). A aventura sociológica: objetividade, paixão, improviso e método na pesquisa social. Rio de Janeiro: Jorge Zahar, 1978. 